\title{
Pemanfaatan Teknologi Droplet Digital PCR (ddPCR) dalam Kegiatan Analisis Molekuler Tanaman
}

\section{(Application of Droplet Digital PCR (ddPCR) Technology for Plant Molecular Biology Analysis)}

\author{
Kristianto Nugroho $^{1,2)}$, Dwi Widyajayantie ${ }^{1,3)} *$, Sayyidah Afridatul Ishthifaiyyah ${ }^{l)}$, Elisa Apriliani ${ }^{1)}$ \\ ${ }^{1)}$ Program Studi Pemuliaan dan Bioteknologi Tanaman, Departemen Agronomi dan Hortikultura, \\ Fakultas Pertanian, Institut Pertanian Bogor, Jl Meranti Kampus IPB Dramaga Bogor 16680 \\ ${ }^{2)}$ Balai Besar Penelitian dan Pengembangan Bioteknologi dan Sumberdaya Genetik Pertanian, Jalan \\ Tentara Pelajar 3A, Cimanggu, Bogor 16111 \\ ${ }^{3)}$ Pusat Penelitian Bioteknologi Lembaga Ilmu Pengetahuan Indonesia (LIPI) Jl. Raya Bogor Km 46 \\ Cibinong, Bogor 16911 \\ *E-mail: dwi.widya869@gmail.com
}

(Article History: Received 23 October 2020; Revised 9 January 2021; Accepted 18 January 2021)

\begin{abstract}
ABSTRAK
Selama beberapa dekade terakhir, teknik PCR memberikan manfaat yang begitu besar dalam kegiatan penelitian di bidang biologi molekuler. Digital droplet PCR (ddPCR) merupakan salah satu teknologi PCR terbaru yang diklaim memiliki keunggulan dibanding teknik qPCR. Prinsip kerja teknik ini yaitu membagi sampel menjadi molekul-molekul kecil yang dipisahkan oleh emulsi minyak, air, dan senyawa penstabil sehingga membentuk droplets. Teknik ini memiliki kelebihan mampu melakukan kuantifikasi absolut maupun relatif pada DNA dengan konsentrasi sangat rendah, tidak memerlukan kurva standar, serta tidak sensitif terhadap kehadiran senyawa inhibitor. Teknik ini telah diaplikasikan pada kegiatan analisis molekuler tanaman di antaranya kegiatan pengukuran konsentrasi DNA dengan sangat akurat, deteksi kehadiran patogen pada jaringan tanaman, dan estimasi jumlah salinan T-DNA pada proses transformasi genetik.

Kata kunci: PCR; droplet digital PCR; DNA; biologi molekuler; alat deteksi
\end{abstract}

\begin{abstract}
Over the past decades, PCR technique has provided enormous benefits in molecular biology research activities. Digital droplet PCR (ddPCR) is one of the latest PCR technologies that is claimed to have advantages over the qPCR technique. The working principle of this technique is to divide the sample into small molecules, which separated by emulsions of oil, water, and stabilizing compounds to form droplets. This technique has the advantage of being able to perform absolute and relative quantification with very low DNA concentrations, does not require a standard curve, and less sensitive to the presence of inhibitor compounds. This technique has been applied to a number of plant molecular analysis, such as for measuring DNA concentrations very accurately, detecting the presence of pathogens in plant tissue, and estimating the copy number of T-DNA in the genetic transformation process.
\end{abstract}

Keywords: PCR; droplet digital PCR; DNA; molecular biology; diagnostic tool.

\section{PENDAHULUAN}

Selama beberapa dekade terakhir, teknologi Polymerase Chain Reaction (PCR) yang dikembangkan oleh Kary Mullis pada tahun 1985 telah memegang peran yang sangat penting dalam menunjang kegiatan penelitian di bidang biologi molekuler (Mullis 1986). Teknik ini memanfaatkan kehadiran enzim Polymerase yang bersifat termostabil untuk mengamplifikasi molekul DNA secara in vitro. Teknik ini mampu memperbanyak segmen DNA tertentu yang telah ditandai oleh primer, dalam jumlah ribuan hingga jutaan copy dalam waktu beberapa jam saja (Handoyo dan Rudiretna 2000).

Kehadiran teknologi PCR telah memberikan sumbangan besar bagi ilmu 
pengetahuan di berbagai bidang. Di bidang pertanian misalnya, teknik PCR dimanfaatkan untuk menganalisis keragaman genetik tanaman, pembuatan sidik jari DNA tanaman, seleksi berbantu marka molekuler, deteksi kehadiran patogen tanaman, hingga rekayasa genetika tanaman (Hidayatun et al. 2011, Meitayani et al. 2014, Efendi et al. 2015, Terryana et al. 2018, Pardal et al. 2020). Di bidang peternakan, teknik PCR telah membantu para pemulia ternak untuk menyeleksi hewan-hewan ternak berdasarkan karakter unggul serta mendeteksi adanya penyakit yang berbahaya bagi ternak (Shiddieqy et al. 2014, Noor 2018). Di bidang kesehatan dan forensik, teknik PCR sangat membantu dalam mendeteksi patogen berbahaya bagi manusia seperti deteksi Plasmodium falciparum dan $P$. vivax yang menjadi penyebab penyakit malaria pada darah manusia, deteksi virus Corona penyebab penyakit Covid-19 yang saat ini sedang mewabah di seluruh dunia, mengidentifikasi korban tindak kriminal atau kecelakaan pada kasus forensik, hingga penelusuran orang tua biologis seorang anak (Kusuma dan Wairocana 2013, Suryadi 2015, Koepfli et al. 2016, Corman et al. 2020)

Begitu besarnya manfaat yang diberikan membuat teknik PCR masih digunakan hingga saat ini. Para peneliti terus melakukan perbaikan dan pengembangan terhadap teknik yang sudah ada. Pada mulanya teknik PCR dikembangkan dari mesin thermocycler sederhana yang suhunya dapat diatur sedemikian rupa sehingga mampu mengakomodasi tiga proses penting yaitu denaturasi, annealing (penempelan primer), dan ekstensi (pemanjangan) (Budiarto 2015). Produk PCR dari teknik tersebut selanjutnya harus diseparasi menggunakan gel kemudian diwarnai dan divisualisasi di bawah sinar UV untuk melihat pola pita DNA yang diihasilkan. Pada teknik ini, kita tidak bisa mengetahui berapa jumlah copy DNA yang dihasilkan dari setiap siklus sehingga teknik ini dikenal dengan sebutan PCR kualitatif.
Para peneliti selanjutnya mengembangkan teknologi Real-Time PCR (RT-PCR) yang tidak hanya mampu mengamplifikasi DNA namun juga mampu melakukan perhitungan berapa banyak jumlah copy DNA yang dihasilkan dari setiap siklusnya secara cepat dan akurat melalui pemanfaatan senyawa fluoresens yang pendarannya dapat ditangkap oleh kamera untuk selanjutnya divisualisasikan langsung pada layar komputer. Oleh karena itu teknik ini dikenal dengan sebutan PCR kuantitatif (quantitative PCR, qPCR). Sayangnya teknik ini masih memiliki beberapa kelemahan yaitu masih terdapatnya tingkat kesalahan (error rate) dalam pembacaan nilai ambang siklus (Cycle Threshold, CT) yang dipengaruhi oleh konsentrasi template yang digunakan, kehadiran senyawa inhibitor, dan tidak adanya kontrol endogen yang benar serta standar prosedur yang baku (Manoj 2014).

Untuk mengatasi kekurangan yang terdapat pada teknik qPCR, para peneliti kemudian berusaha mengembangkan teknologi yang disebut digital PCR (dPCR). Konsep mengenai dPCR sendiri pertama kali dikembangkan oleh Sykes bersama timnya pada tahun 1992 dengan menggunakan teknik PCR tersarang (Sykes 1992). Salah satu teknik dPCR yang baru dikembangkan beberapa tahun belakangan ini yaitu teknik droplet digital PCR (ddPCR). Teknik ini memanfaatkan kelebihan dari PCR konvensional dengan penghitungan secara akurat menggunakan statistika Poisson. Teknik ini diklaim mampu melakukan penghitungan jumlah copy lebih akurat dibanding qPCR tanpa memerlukan kurva standar; mampu menoleransi kehadiran senyawa inhibitor; dan mampu mendeteksi kehadiran alel dengan frekuensi kurang dari 1\% (Manoj 2014). Kehadiran teknologi ddPCR diharapkan bisa mengatasi kekurangan yang selama ini masih ditemukan pada teknik qPCR sehingga kegiatan analisis molekuler dapat memberikan hasil yang lebih akurat dan presisi. 


\section{PRINSIP KERJA ddPCR}

Teknik ddPCR digunakan untuk mengkuantifikasi asam nukleat dengan cara membagi sampel menjadi molekul-molekul kecil (partitions atau reaction chamber), dimana beberapa reaction chamber mengandung satu atau lebih copy DNA target dan lainnya tidak mengandung copy DNA target. Reaction chamber dipisahkan oleh emulsi minyak, air, dan senyawa penstabil sehingga membentuk droplets (Manoj 2014, Nyaruaba et al. 2019). Setiap sampel dapat terbagi menjadi 20.000 droplets bahkan lebih, tergantung kapabilitas alat yang digunakan. Masing-masing droplet mengandung fluorescence labeled probe sebagai pendeteksi yang membedakan antara droplet positif (droplet yang mengandung sekuens DNA target) dengan droplet negatif. Reaksi amplifikasi berjalan secara terpisah pada setiap reaction chamber melalui thermal cycling sehingga tidak ada kompetisi yang terjadi antara molekul DNA target dengan DNA background. Hal tersebut yang menjadikan ddPCR lebih akurat dibandingkan qPCR karena dapat mendeteksi DNA target meski dalam jumlah yang sedikit.

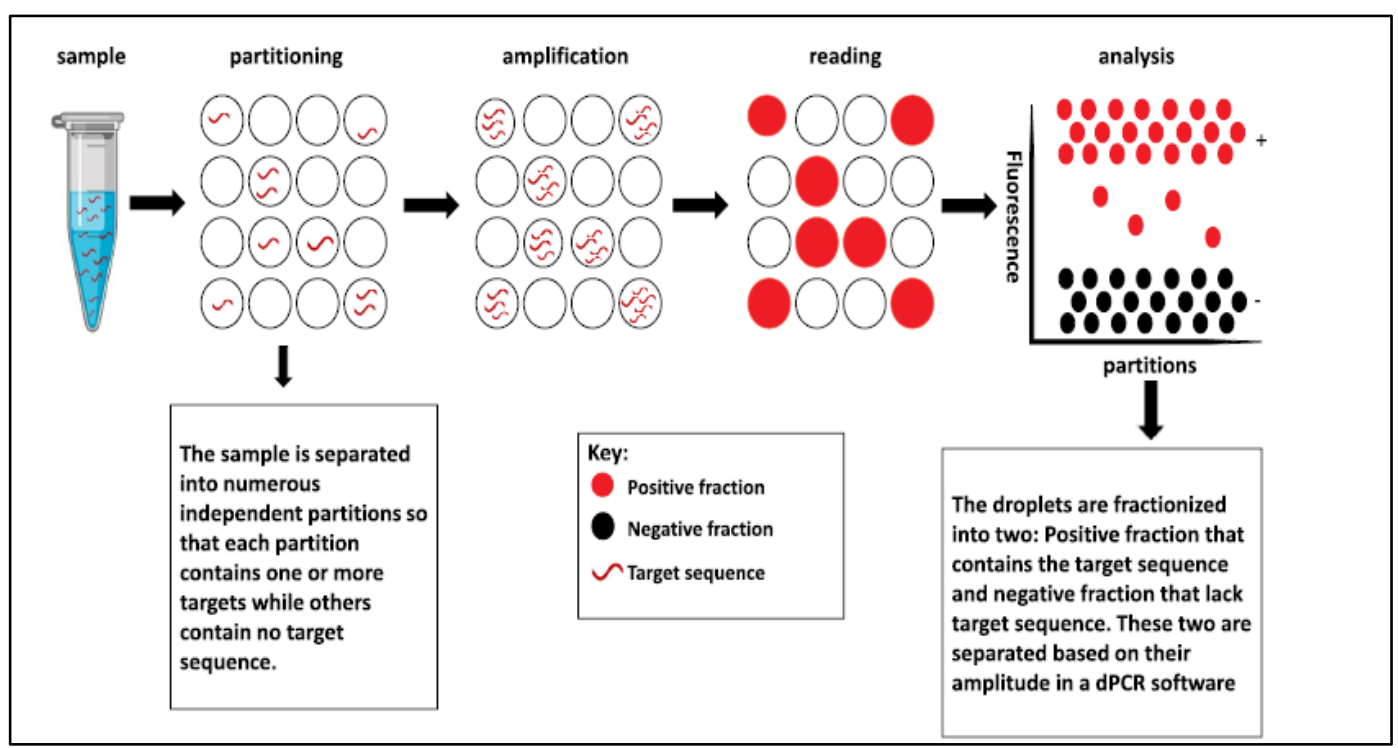

Gambar 1. Prinsip dasar digital Polymerase Chain Reaction (dPCR) (Nyaruaba et al. 2019)

Manoj (2014) dan Mao et al. (2019) menjelaskan bahwa hasil PCR kemudian dibaca oleh mesin yang fungsinya seperti flow cytometry, yaitu menganalisis setiap droplet dan mengecek apakah terjadi reaksi atau tidak dengan cara menghitung jumlah droplet positif dan droplet negatif. Reaksi tanpa molekul target dihitung 0, sedangkan reaksi dengan 1 molekul target dihitung 1 . Jumlah awal copy dan density DNA dihitung dengan statistik Poisson dan jumlah reaksi positif PCR. Dalam hal ini, jumlah bagian atau droplets yang berwarna (merah) sama dengan molekul DNA target (Gambar 1). Jumlah molekul DNA target yang dihasilkan dapat dikalkulasi berdasarkan jumlah fraksi positif pada akhir reaksi berdasarkan statistika Poisson dengan rumus sebagai berikut (Hindson et al. 2011):

$$
\lambda=-\ln (1-p)
$$

dengan $\lambda$ adalah rata-rata jumlah molekul DNA target yang dihasilkan per reaksi ulangan dan $\mathrm{p}$ adalah fraksi positif yang dihasilkan pada akhir reaksi. Kuantifikasi molekul DNA secara independen (tanpa kurva standar) memberikan hasil yang lebih akurat dibandingkan dengan qPCR, terutama jika terdapat kontaminan pada sampel yang dapat menghambat aktivitas Taq polymerase dan/atau penempelan primer (Sean et al. 2017).

Alur kerja dari teknik ddPCR memerlukan beberapa tahapan yang harus dilakukan secara teliti dan hati-hati seperti 
yang dipaparkan oleh Hindson et al. (2011) (Gambar 2). Pertama, sampel dan droplet generator oil dimasukkan ke dalam droplet generator cartridge yang terdiri atas delapan kanal. Selanjutnya cartridge dimasukkan ke dalam alat droplet generator. Di dalam alat tersebut terdapat sebuah vakum yang akan menarik sampel dan minyak untuk mengalir melewati sebuah lubang (nozzle), di mana setelah melewati lubang tersebut gabungan sampel dengan minyak akan membentuk 1 $\mathrm{nL}$ droplet. Dalam waktu kurang dari dua menit, delapan sampel berhasil diubah menjadi delapan set yang terdiri atas 20.000 droplet. Droplet-droplet yang terbentuk bersifat stabil kemudian dipindahkan ke 96 well plate dengan cara dipipet.

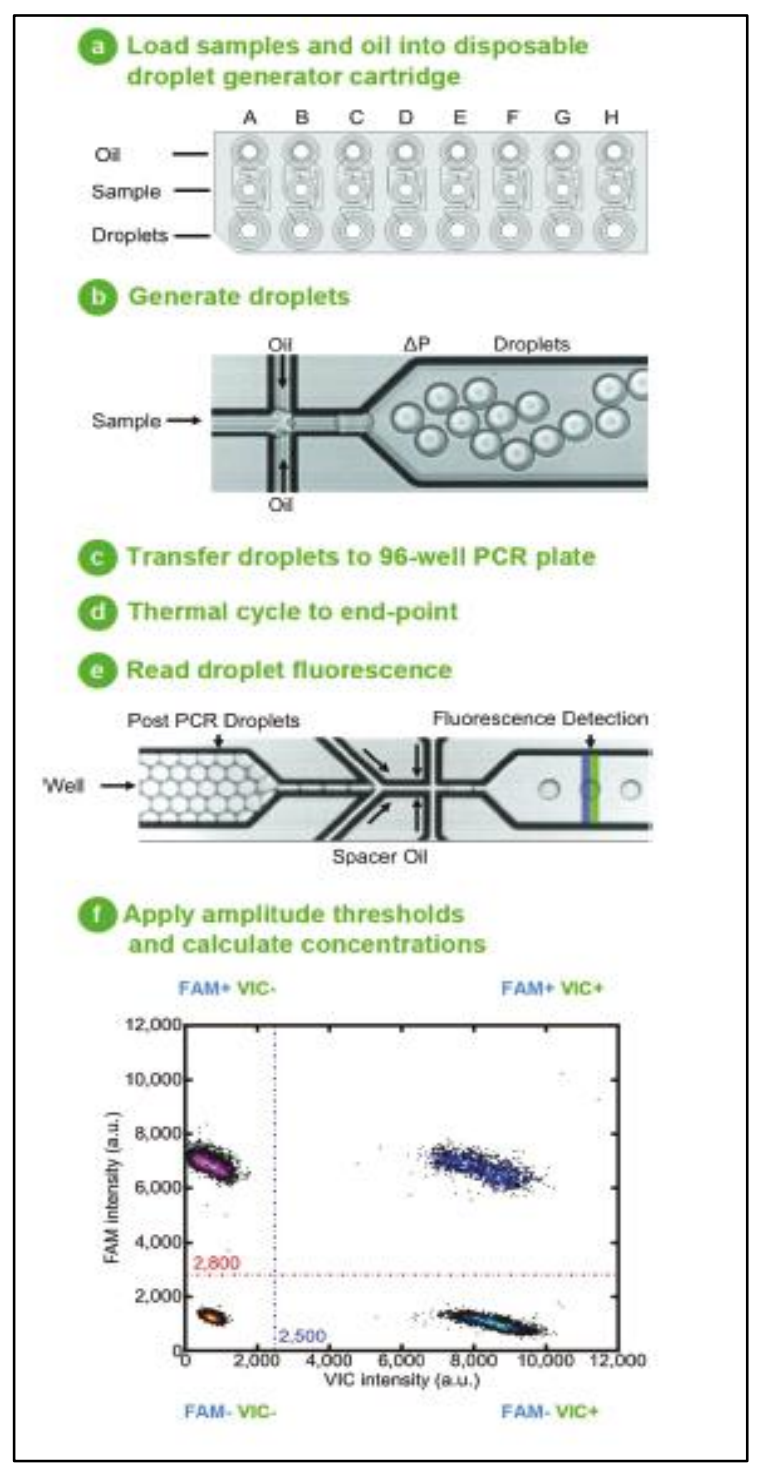

Gambar 2. Alur kerja teknik ddPCR (Hindson et al. 2011).
Sampel selanjutnya diamplifikasi dalam mesin thermal cycler sebanyak 35-45 siklus. Setelah proses amplifikasi selesai, $P C R$ plate selanjutnya dipindahkan ke dalam alat droplet reader di mana setiap droplet akan dilewatkan melalui suatu detektor yang mampu mendeteksi perbedaan warna berdasarkan pendaran senyawa fluoresens yang digunakan. Droplet yang melewati detektor dapat dibaca sebagai fraksi positif atau negatif menurut amplitudo dari pendaran fluorosens yang dihasilkan. Droplet yang positif mengadung DNA template akan memiliki pendaran warna yang lebih kuat. Jumlah droplet postif dan negatif pada setiap kanal digunakan untuk menghitung konsentrasi DNA target dan referensi berdasarkan persamaan Poisson.

\section{KELEBIHAN DAN KEKURANGAN ddPCR DIBANDING TEKNIK PCR LAINNYA}

\section{Kelebihan ddPCR}

Droplet digital polymerase chain reaction (ddPCR) merupakan teknik biologi molekuler baru yang dapat memberikan kuantifikasi absolut maupun relatif pada target asam nukleat tanpa memerlukan kalibrator eksternal maupun kurva kaibrasi seperti yang biasa digunakan dalam qPCR (Whale et al. 2012, Zhao et al. 2016). Kurva kalibrasi eksternal untuk kuantifikasi absolut pada qPCR biasanya diperoleh dari serangkaian pengenceran yang telah diketahui konsentrasinya, biayanya mahal karena memerlukan bahan referensi standar metrologi, sulit dan memakan waktu pada saat preparasi sampel (Kim et al. 2013). Selain itu masalah utama penggunaan qPCR kuantitatif adalah terbatasnya ketersediaan bahan referensi untuk menghasilkan kurva dan batasan standar saat menggunakan jumlah DNA cetakan dengan konsentrasi yang lebih tinggi (Demeke et al. 2014).

Pada teknik ddPCR, pengaruh senyawa inhibitor yang selama ini terdapat dalam qPCR, dapat dikurangi secara signifikan. Hal ini disebabkan adanya pengumpulan sinyal fluoresens pada titik-akhir (end point) 
dan penghitungan droplet positif atau negatif secara binomial yang dikaitkan dengan algoritma Poisson (Zhao et al. 2016). Dapat dikatakan ddPCR memiliki toleransi yang lebih besar terhadap inhibitor (Whale et al. 2012). Sementara itu, qPCR lebih sensitif terhadap inhibitor PCR, yang dapat menurunkan efisiensi PCR sehingga menyebabkan pergeseran $\mathrm{Cq}$ ke nilai yang lebih besar dan terlalu rendahnya konsentrasi (Gambar 3). Kehadiran inhibitor memiliki potensi untuk meningkatkan kesalahan, mengurangi resolusi pengujian dan hasil yang tidak sesuai, termasuk hasil false negative dalam PCR kuantitatif maupun kualitatif (Hugget et al. 2008).

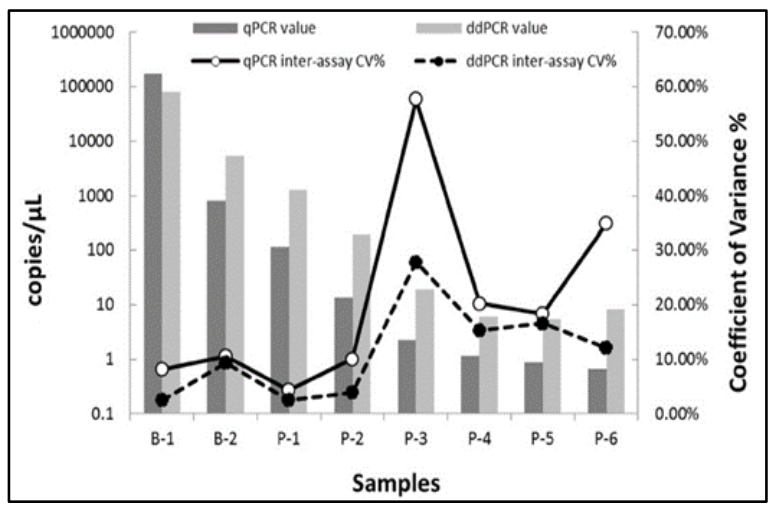

Gambar 3. Perbandingan nilai CV (Coefficient of Variance) dan nilai ketelitian pendeteksian target berkonsentrasi rendah pada ddPCR dan qPCR (Zhao et al. 2016).

Pengujian menggunakan teknik ddPCR menunjukkan koefisien variasi yang lebih rendah dibandingkan dengan qPCR, terutama pada target DNA dengan konsentrasi rendah sehingga dapat dikatakan bahwa hasil ddPCR menunjukkan keberulangan (repeatability) yang lebih baik pada target yang berkonsentrasi rendah (Whale et al. 2012, Zhao et al. 2016, Gossen et al. 2019). Penyimpanan dan penanganan kalibrator eksternal atau bahan DNA referensi pada qPCR dapat menyebabkan terjadinya degradasi bahan tersebut sehingga membuat hasil deteksi kuantitatif bervariasi dari hari ke hari atau nilai repeatability nya rendah (Hou et al. 2010). Reproduksibilitas dari qPCR dan ddPCR dapat dievaluasi berdasarkan nilai koefisien variansnya (CV). Pada Gambar 4 pengujian dengan ddPCR menunjukkan adanya peningkatan reproduktivitas $\quad(\mathrm{CV}: \quad 0,9 \quad-\quad 17,6 \%)$ dibandingkan dengan qPCR (CV: 5,1 $41 \%)$.

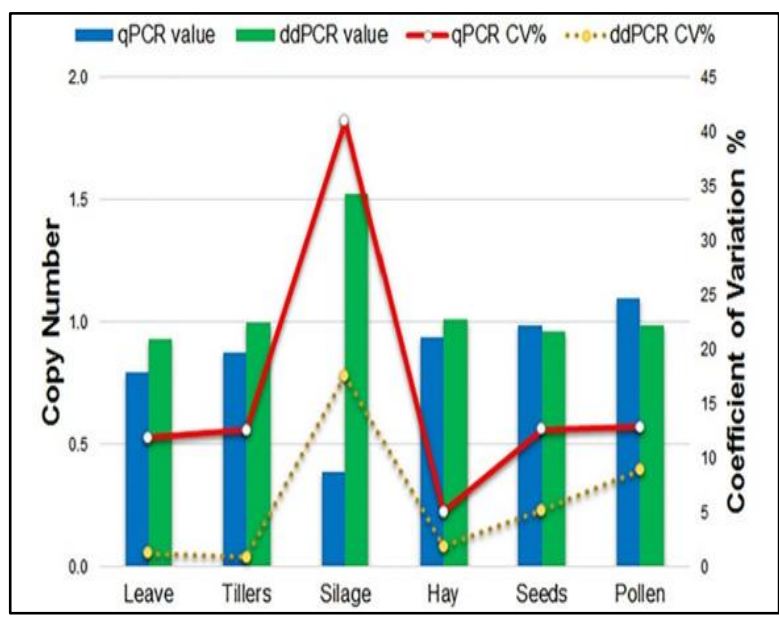

Gambar 4. Perbandingan qPCR dan ddPCR pada semua komoditas pertanian. Histogram menunjukkan jumlah salinan relatif rata-rata di setiap jaringan (skala kiri) dan garis menunjukkan variasi atau $\mathrm{CV} \%$ (skala kanan) dari qPCR dan ddPCR (Giraldo et al. 2019).

Penggunaan ddPCR menunjukkan nilai presisi dan akurasi yang lebih tinggi pada deteksi kuantitatif Xanthomonas. citri subsp. citri (bakteri patogen penyebab penyakit Citrus Bacterial Cancer pada tanaman jeruk) dibandingkan dengan hasil uji qPCR (Tabel 1). Hal ini disebabkan dalam sistem ddpCR terdapat partisi-partisi berupa droplet yang berisi fraksi positif atau negatif dari asam nukleat yang akan diukur dengan menghitungnya berdasarkan persamaan Poisson. Hasil uji ddPCR memiliki rentang dinamis yang lebih luas serta tingkat sensitivitas pengukuran yang jauh lebih tinggi dibandingkan dengan qPCR (Zhao et al. 2016; Ristaino et al. 2020). Dalam pengujiannya, teknik ddPCR dapat mendeteksi keberadaan DNA yang jumlah salinannya rendah dalam satuan molekul per mikroliter. 
Tabel 1. Data perbandingan pengujian ddPCR dan qPCR dalam mendeteksi Xcc pada tanaman jeruk yang terinfeksi (Zhao et al. 2016)

\begin{tabular}{|c|c|c|c|c|}
\hline \multirow{2}{*}{$\begin{array}{c}\text { Sampel } \\
\text { Jeruk } \\
\text { Terinfeksi }\end{array}$} & \multicolumn{2}{|c|}{ ddPCR } & \multicolumn{2}{c|}{ qPCR } \\
\cline { 2 - 5 } & Positif & Negatif & Positif & Negatif \\
\hline Simptomatik & 25 & 0 & 22 & 3 \\
\hline Asimptomatik & 21 & 4 & 9 & 16 \\
\hline
\end{tabular}

\section{Kekurangan ddPCR}

Teknik ddPCR diklaim mampu menoleransi kehadiran senyawa inhibitor pada prosesnya dan tidak sensitif terhadap inhibitor seperti pada teknik qPCR. Namun kenyataannya, kehadiran beberapa senyawa inhibitor seperti etanol masih dapat mempengaruhi proses ddPCR. Iwobi et al. (2016) menyatakan bahwa kehadiran senyawa tersebut dapat menghambat stabilitas reaksi ddPCR, sehingga sangatlah penting untuk memastikan bahwa DNA yang digunakan memiliki kualitas dan kemurnian yang baik sebelum digunakan untuk pengujian ddPCR.

Selain etanol, masih terdapat senyawa lain yang dapat menghambat kerja reagen yang digunakan pada teknik ddPCR. Dingle et al. (2013) melakukan pengujian menggunakan beberapa senyawa inhibitor yang umum dijumpai pada reaksi PCR seperti SDS (Sodium Dodecyl Sulfate), EDTA (Ethylendiamine tetraaceate), dan heparin baik pada reaksi ddPCR maupun qPCR. Hasilnya menunjukkan bahwa ddPCR memiliki kemampuan yang baik dalam menoleransi kehadiran senyawa SDS dan heparin. Sementara itu baik teknik ddPCR maupun qPCR, tidak mampu menoleransi kehadiran senyawa EDTA pada reaksinya. Hal ini disebabkan karena sifat dari EDTA yang cenderung mengikat kation bivalen seperti $\mathrm{Mg}^{2+}$ yang dibutuhkan sebagai kofaktor enzim Taq Polymerase.

Selain masalah kehadiran senyawa inhibitor, tingkat akurasi dalam kuantifikasi absolut juga menjadi salah satu isu penting dalam metode ini. Tingkat akurasi sangat bergantung pada volume partisi berupa volume tetesan yang digunakan. Jika volume tetesan bervariasi antara reaksi dan droplet generator, maka dapat terjadi underestimate atau overestimate dari jumlah salinan. Pada penggunaan ddPCR, terjadi ketidakserasian antara volume droplets yang ditentukan oleh pabrikan dengan volume partisi yang dihitung secara manual. Kosir et al. (2017) melaporkan bahwa pada penggunaan mesin BIO-rad QX100 Droplet Digital Generator DG8 dengan perangkat lunak QuantaSoft 1.3.2.0 pengaturan volume droplet menujukkan angka 0,91 nL, akan tetapi setelah dilakukan pengukuran volume pada tetesan generator, volume tetesan yang ditunjukkan lebih kecil dari yang diyakini sebelumnya yaitu 0,89 nL. Selain itu, volume droplet juga dipengaruhi oleh jenis supermix (probe atau EVAGreen) dan generator droplets yang digunakan.

Pengukuran volume yang tidak tepat dapat menjadi masalah terutama dalam aplikasi di bidang kesehatan. Pengukuran volume yang tidak tepat akan mempengaruhi pengambilan keputusan diagnostik dan klinis dalam pelabelan salah satu produk atau kesalahan dalam pengobatan. Dengan demikian salah satu hal yang perlu diperhatikan dalam penentuan kuantifikasi jumlah salinan secara akurat adalah ukuran volume droplet yang diukur dengan mengantisipasi semua kemungkinan penurunan volume, serta penggunaan jenis generator droplet. Selain itu jenis supermix yang digunakan juga menjadi salah satu faktor yang harus dipertimbangkan.

Kekurangan lain dari teknik ddPCR yaitu perlunya dilakukan beberapa optimasi konsentrasi primer dan probe yang berpotensi meningkatkan kinerja pengujian secara keseluruhan. Tingkat ketelitian evaluasi dan verifikasi sangat penting, terutama untuk pengujian yang dilakukan dalam format ddPCR multipleks. Hasil perhitungan efesiensi biaya menunjukkan bahwa untuk pengujian simplex, teknik qPCR menunjukkan efisiensi yang lebih baik, namun untuk pengujian multiplex ddPCR mampu menggeser qPCR dalam efesiensi harga dan waktu yang diperlukan. 
Pada penelitian yang dilakukan Yang et al. (2014) dilakukan perbandingan antara waktu dan biaya yang dibutuhkan untuk melakukan analisis menggunakan ddPCR dan qPCR. Hasilnya menunjukkan bahwa untuk melakukan analisis satu sampel menggunakan ddPCR, diperlukan waktu sekitar 2.7 jam sedangkan pada qPCR dibutuhkan waktu sekitar 2.2 jam. Sementara itu, untuk melakukan analisis menggunakan ddPCR dibutuhkan biaya sekitar AUD 61.00 per sampelnya sedangkan untuk analisis menggunakan qPCR menghabiskan biaya sebanyak AUD 50.00 .

\section{PEMANFAATAN ddPCR PADA TANAMAN}

\section{1) Pengukuran konsentrasi DNA tanaman secara akurat}

Salah satu bentuk pemanfaatan teknik ddPCR dalam kegiatan analisis molekuler pada tanaman yaitu pada pengukuran konsentrasi DNA hasil ekstraksi seperti yang yang dilakukan oleh Scollo et al. (2016). Pada penelitian tersebut, Scollo et al. (2016) mencoba membandingkan beberapa metode ekstraksi DNA pada tanaman zaitun, yang merupakan salah satu tanaman pertanian penting yang dimanfaatkan minyaknya. Selama ini telah banyak metode ekstraksi DNA yang dikembangkan pada tanaman tersebut namun metode untuk pengukuran kualitas maupun kuantitas DNA masih belum memuaskan.

Kegiatan ekstraksi DNA dilakukan dari minyak zaitun langsung menggunakan tiga varietas yaitu "Biancolilla", "Nocellara Etnea", dan "Tonda Iblea". DNA diekstraksi menggunakan empat macam metode yaitu: 1) CTAB dengan kolom purifikasi dan reagen DNeasy Plant Maxi Kit (Qiagen, Germany); 2) metode CTAB dengan purifikasi menggunakan chloroform; 3) kit NucleoSpin Plant II Maxi (MachereyNagel, Germany); dan 4) kit NucleoSpin Plant II Maxi dengan sedikit modifikasi. Sebagai pembanding, DNA juga diekstraksi dari bagian daun yang berasal dari varietas
"Picual" menggunakan metode CTAB. DNA hasil ekstraksi selanjutnya diamplifikasi menggunakan sepasang primer yang didisain dari lokus $11 \mathrm{C}$ kloroplas untuk melihat hasil (yield) dan kemurniannya. Amplifikasi dilakukan menggunakan ddPCR maupun qPCR untuk membandingkan manakah di antara kedua alat tersebut yang lebih akurat untuk digunakan.

Hasil analisis menunjukkan bahwa ddPCR memberikan resolusi yang lebih baik, dengan kemampuan melakukan amplifikasi sampel pada nilai pengenceran yang lebih kecil. Penggunaan qPCR menunjukkan bahwa konsentrasi DNA terendah yang secara statistik masih memungkinkan untuk diamplifikasi yaitu sebesar $10^{-2} \mathrm{ng} / \mathrm{ul}$ sedangkan pada ddPCR nilai pengenceran terendah yaitu pada konsentrasi $10^{-3} \mathrm{ng} / \mathrm{ul}$ (Gambar 5 dan 6) (Scollo et al. 2016). Hal ini menunjukkan bahwa ddPCR memiliki kemampuan mendeteksi DNA pada konsentrasi yang lebih rendah dibanding qPCR.

Nilai regresi linear ddPCR sebesar 0,9972 menunjukkan perbedaan yang tidak terlalu besar dengan nilai regresi linear qPCR (0,9965), meskipun demikian perbedaan kecil tersebut bermakna sangat signifikan pada tingkat sensitifitas kedua alat tersebut. Sayangnya meskipun tingkat sensitifitas ddPCR lebih tinggi, namun di sisi lain ddPCR memerlukan sebuah sistem PCR khusus, yang memerlukan biaya yang lebih mahal dibanding teknik fluorometri atau spektrofotometri.

\section{2) Deteksi kehadiran patogen pada tanaman}

Infeksi patogen pada tanaman pertanian, seringkali menyebabkan kerugian berupa penurunan hasil panen hingga kematian tanaman. Kehadiran patogen pada jaringan tanaman seringkali sulit dideteksi sejak dini karena ukurannya yang sangat kecil dalam bentuk spora atau miselium. Saat ini kehadiran patogen dapat dideteksi sejak dini, melalui pemanfaatan teknik ddPCR seperti pada penelitian yang dilakukan oleh Ristaino et al. (2020). Pada penelitian tersebut, 
mereka melakukan deteksi kehadiran cendawan Phytophthora infestans pada umbi kentang dengan membandingkan penggunaan teknik Loop-Mediated Isothermal Amplification (LAMP), RealTime LAMP (RT LAMP), dan ddPCR.
LAMP merupakan metode amplifikasi DNA sederhana yang hanya menggunakan satu temperatur. Oleh karena itu amplifikasi tidak harus dilakukan menggunakan mesin thermocycler tetapi dapat dilakukan menggunakan heat block atau waterbath.

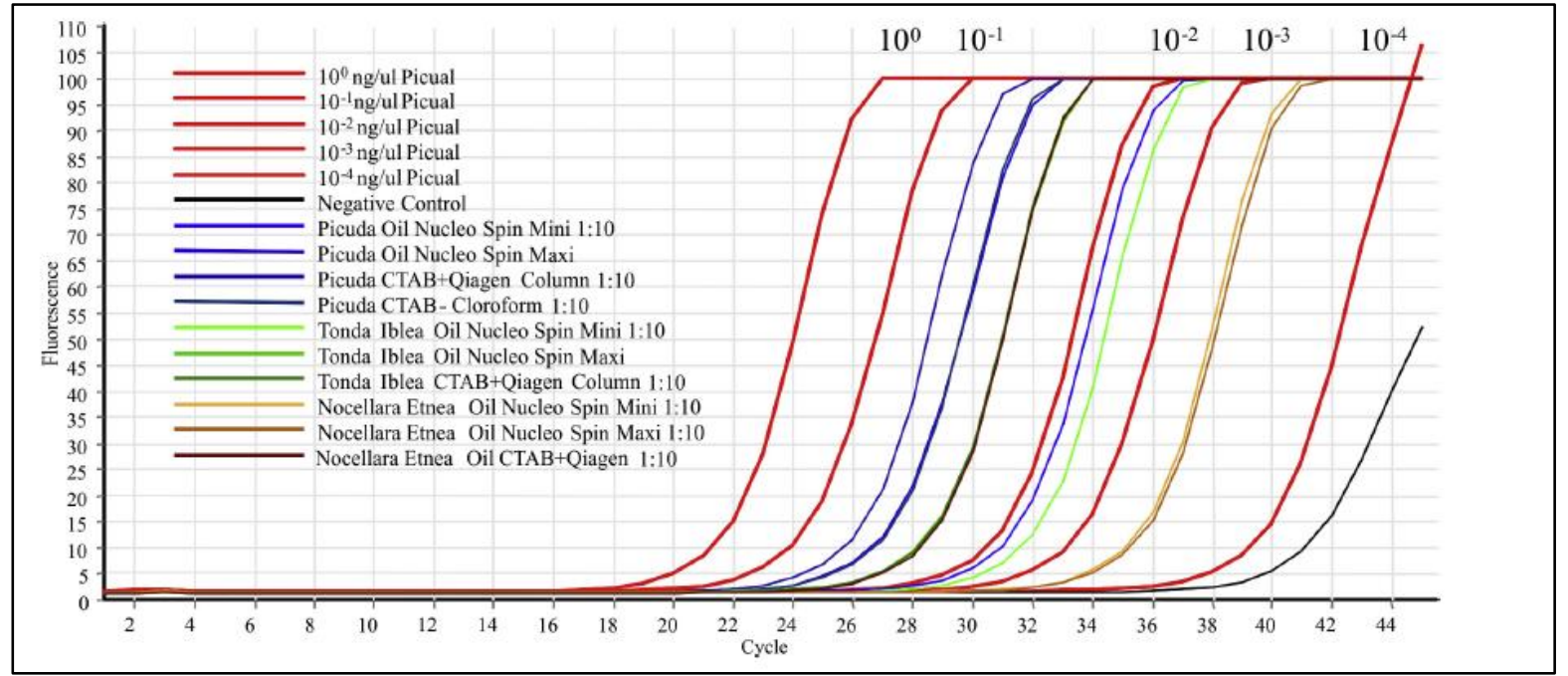

Gambar 5. Hasil amplifikasi DNA zaitun menggunakan qPCR (Scollo et al. 2016).

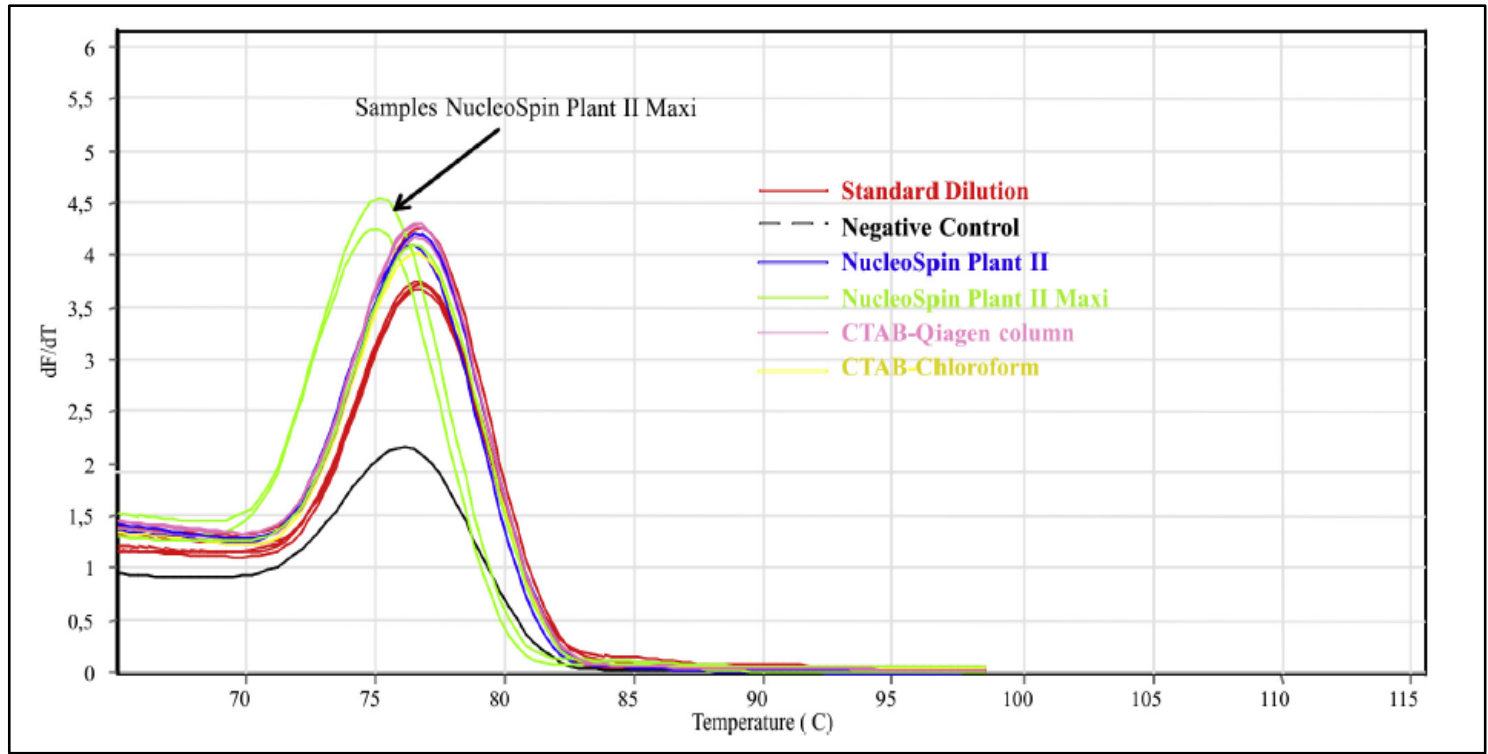

Gambar 6. Hasil amplifikasi DNA zaitun menggunakan ddPCR (Scollo et al. 2016).

Sebanyak delapan isolat $P$. infestans yang berasal dari Amerika Serikat dan satu isolat yang berasal dari Eropa dan Afrika Timur digunakan pada penelitian ini. DNA diekstraksi secara manual menggunakan metode CTAB. Terdapat tiga pasang primer yang digunakan untuk amplifikasi menggunakan metode LAMP yaitu primer forward dan reverse standar (F3/B3), FIP/BIP primer, dan dua primer Loop untuk mempercepat reaksi yaitu LoopF/LoopB. Ketiga pasang primer tersebut didisain pada daerah ITS. 
Tabel 2. Konsentrasi pengenceran DNA minimum yang dapat diamplifikasi pada beberapa metode PCR (Ristaino et al. 2020)

\begin{tabular}{lllll}
\hline Konsentrasi & PCR & LAMP & $\begin{array}{l}\text { RT } \\
\text { LAMP }\end{array}$ & ddPCR \\
& & & & LAM \\
\hline $10 \mathrm{ng} / \mathrm{ul}$ & + & + & + & + \\
$1 \mathrm{ng} / \mathrm{ul}$ & + & + & + & + \\
$100 \mathrm{pg} / \mathrm{ul}$ & + & + & + & + \\
$10 \mathrm{pg} / \mathrm{ul}$ & + & + & + & + \\
$1 \mathrm{pg} / \mathrm{ul}$ & - & + & + & + \\
$100 \mathrm{fg} / \mathrm{ul}$ & - & - & - & + \\
\hline
\end{tabular}

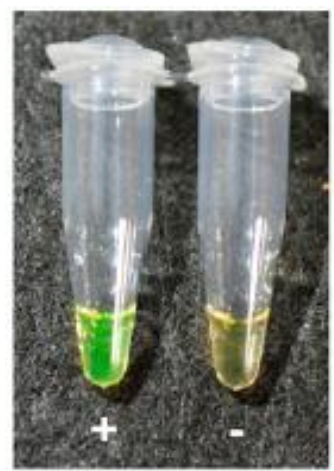

Gambar 7. Hasil amplifikasi sampel kentang menggunakan metode LAMP konvensional. Adanya perubahan warna menunjukkan bahwa sampel positif terinfeksi cendawan (Ristaino et al. 2020).

Hasil analisis menggunakan metode LAMP menunjukkan bahwa metode tersebut mampu mengamplifikasi DNA $P$. infestans hingga pengenceran terendah sebesar 1,1 pg/ul (Tabel 2). Hal ini terlihat dari adanya perubahan warna SYBR Green pada campuran dari semula berwarna hijau menjadi berwarna kuning, yang tidak terjadi pada kontrol negatif (Gambar 7). Sementara itu pada hasil analisis menggunakan RT LAMP, terlihat bahwa konsentrasi pengenceran minimum yang dapat diamplifikasi yaitu sebesar $1,1 \mathrm{pg} / \mathrm{ul}$ sama seperti pada metode LAMP konvensional (Tabel 2, Gambar 8). Perubahan warna juga terjadi pada senyawa HNB yang terdapat pada campuran dari semula berwarna biru tua menjadi berwarna biru cerah, yang tidak terjadi pada kontrol negatif (Gambar 9).

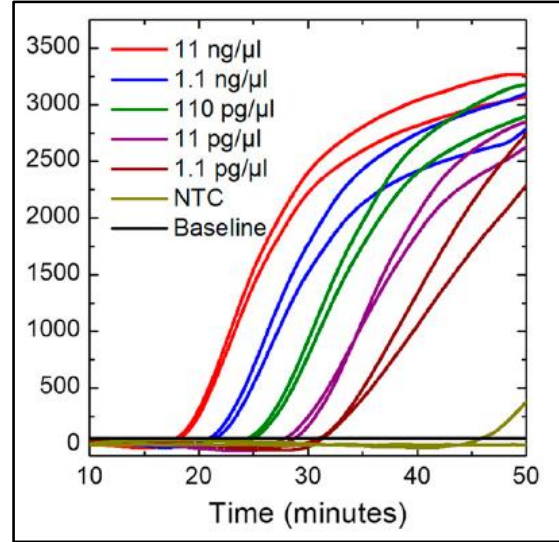

Gambar 8. Hasil amplifikasi sampel kentang menggunakan metode RT LAMP (Ristaino et al. 2020).

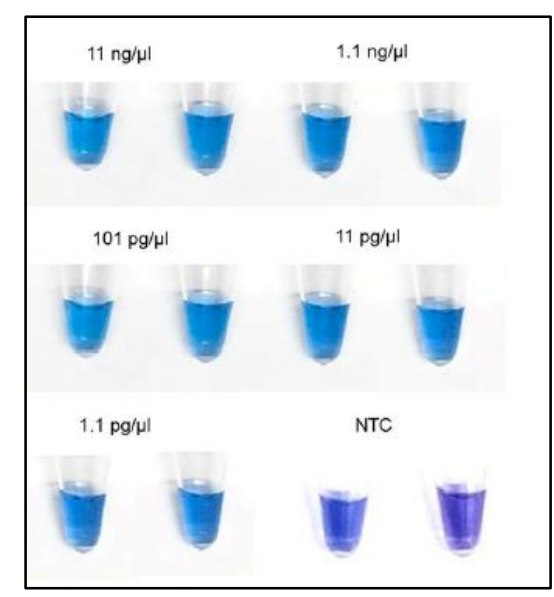

Gambar 9. Perubahan warna pada sampel yang diamplifikasi menggunakan RT LAMP (Ristaino et al. 2020).

Hasil analisis menggunakan ddPCR menunjukkan bahwa metode ini mampu mengamplifikasi sampel pada konsentrasi pengenceran yang lebih rendah yaitu sebesar $100 \mathrm{fg} / \mathrm{ul}$ (Tabel 2). Selain itu, metode ddPCR mampu membedakan antara umbi yang sehat dengan umbi yang terinfeksi dari sebaran titik-titik pada koordinat (Gambar 10). Pada koordinat A terlihat bahwa hanya terdapat satu warna pada titik-titik yang tersebar yaitu warna hitam dengan nilai amplitudo di bawah 3000. Hal ini menunjukkan bahwa sampel yang dianalisis berasal dari umbi yang sehat dan tidak terinfeksi. Sementara pada koordinat B terlihat bahwa terdapat dua warna pada titiktitik yang tersebar yaitu warna hitam dengan nilai amplitudo di bawah 3000 dan warna 
biru dengan nilai amplitudo lebih dari 3000 yang menunjukkan bahwa sampel yang dianalisis berasal dari umbi yang terinfeksi dan selama terjadi reaksi amplifikasi ddPCR, sampel tersebut dipartisi menjadi fraksi positif dan fraksi negatif.

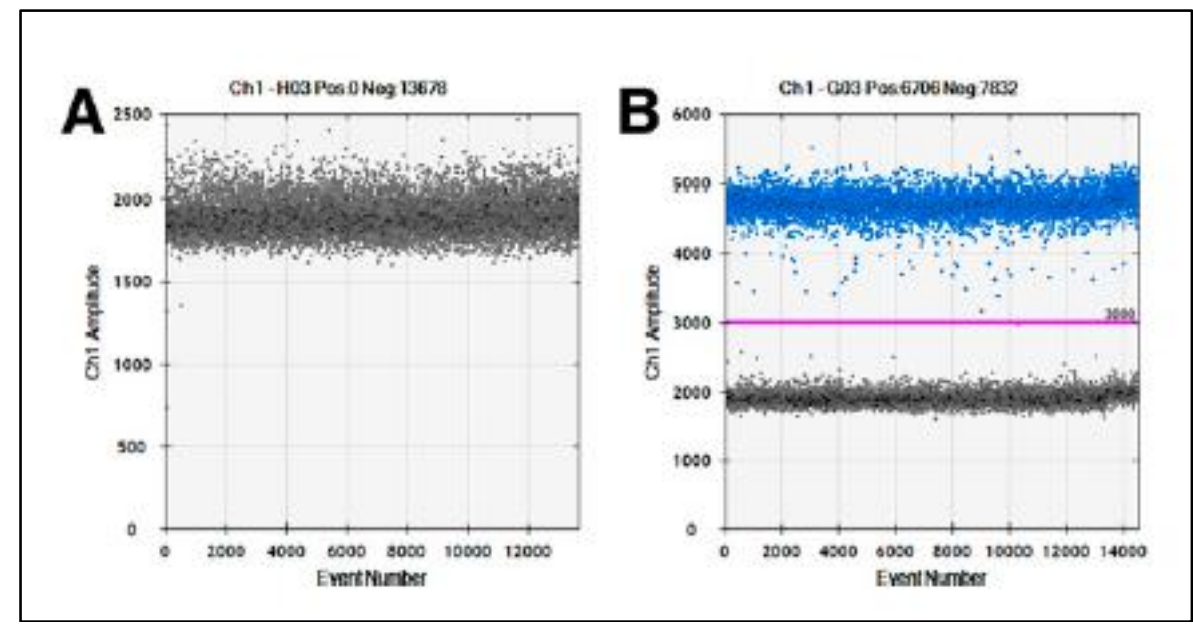

Gambar 10. Hasil amplifikasi menggunakan sampel kentang menggunakan metode ddPCR (Ristaino et al. 2020).

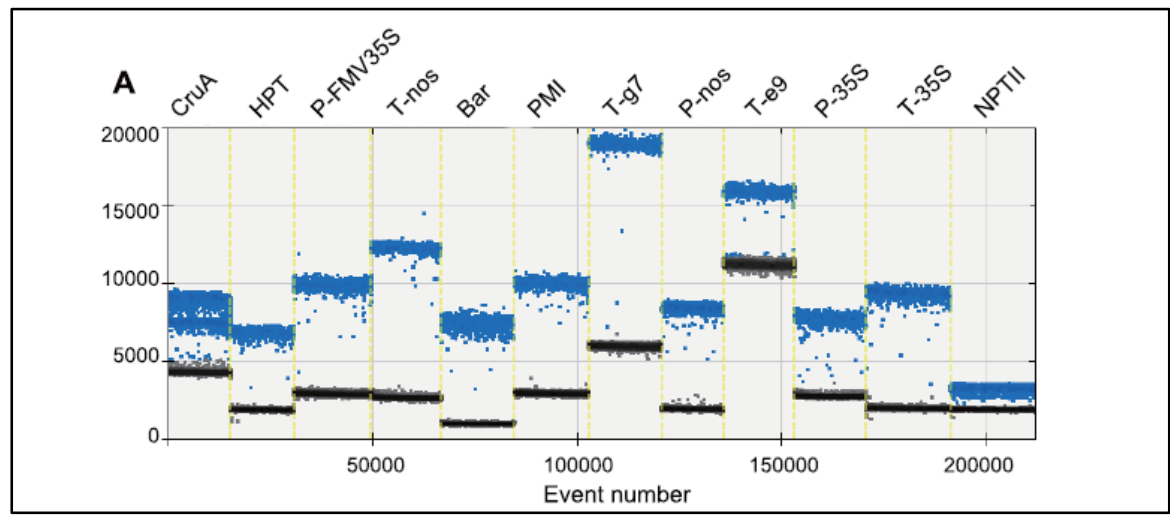

Gambar 11. Plot amplifikasi pada singleplex ddPCR pada kondisi teroptimasi (Wu et al. 2017).

Tabel 3. Estimasi zigositas pada tanaman T1 menggunakan duplex ddPCR (Wu et al. 2017)

\begin{tabular}{clllllllll}
\hline $\begin{array}{c}\text { Tanaman } \\
\text { T1 }\end{array}$ & Target & \multicolumn{3}{c}{ Deteksi Droplet } & \multicolumn{3}{c}{ Statistik Poisson (salinan) } & Rasio & Zigositas \\
& & Accepted & Positif & Negatif & Maksimum & Minimum & $\begin{array}{c}\text { Salinan } \\
\text { per ul }\end{array}$ & & \\
\hline $2-1$ & HPT & 10938 & 3891 & 7047 & 534 & 501 & 517 & 0,50 & Homo \\
& CruA & 10938 & 6417 & 4521 & 1066 & 1013 & 1039 & & \\
$2-2$ & HPT & 13089 & 1714 & 11375 & 173 & 157 & 165 & 0,25 & Hemi \\
& CruA & 13089 & 5598 & 7491 & 674 & 639 & 657 & & \\
\hline
\end{tabular}

3) Estimasi jumlah salinan DNA pada proses transformasi genetik

Saat proses transformasi genetik pada tanaman, DNA yang membawa karakter yang diinginkan dapat disisipkan ke dalam genom tanaman melalui perantaraan Agrobacterium tumefaciens atau menggunakan particle bombardment.
Jumlah salinan DNA yang berhasil dinsersikan akan mempengaruhi tingkat ekspresi gen dan stabilitas genetik dari tanaman transgenik yang dihasilkan. Oleh karena itu estimasi penghitungan jumlah salinan T-DNA yang berhasil disisipkan menjadi sangat penting untuk dilakukan. 
Selama ini teknik Southern blot banyak digunakan untuk kegiatan analisis tersebut, akan tetapi teknik ini memiliki kelemahan yaitu membutuhkan waktu yang lama, keterampilan yang tinggi, serta memerlukan probe radioaktif dengan jumlah material tanaman yang dibutuhkan cukup banyak. Biasanya setelah mengidentifikasi singlecopy pada tanaman $\mathrm{T} 0$, benih $\mathrm{T} 1$ yang diperoleh dari selfing tanaman T0 dapat dibedakan menjadi 3 genotipe yaitu homozigot, hemizigot, dan tidak membawa transgen. Penentuan zigositas dilakukan berdasarkan analisis segregasi pada T2 menggunakan metode PCR atau marka selektif antibiotik. Kehadiran teknik ddPCR dapat mengatasi permasalahan yang ditemukan pada teknik Southern karena kemampuan ddPCR untuk melakukan penghitungan jumlah molekul DNA walaupun dalam jumlah yang sangat kecil seperti yang ditunjukkan pada penelitian yang dilakukan oleh Wu et al. (2017) pada kegiatan transformasi genetik tanaman kanola.

Hasil amplifikasi pada penelitian ini menunjukkan separasi antara droplet positif (warna biru) dan negatif (warna hitam) yang terlihat jelas (Gambar 11). Estimasi jumlah salinan pada tanaman hasil transformasi juga dapat dilakukan dengan baik. Jumlah droplet positif dan negatif dapat dihitung menggunakan perangkat lunak dari ddPCR. Hanya sampel dengan jumlah lebih dari 10.000 droplet yang digunakan dalam analisis. Selain itu zigositas pada tanaman generasi $\mathrm{T} 1$ yang juga dapat diestimasi. Zigositas pada tanaman T1 yang berasal dari selfing tanaman T0 tediri atas tiga genotipe yang perbandingannya mengikuti nisbah Mendel, yaitu homozigot, hemizigot, dan bukan transgenik. Hasil analisis menunjukkan bahwa ada beberapa tanaman yang memiliki nilai rasio antara gen eksogen dengan gen endogen sebesar 0,5 yang berarti bahwa tanaman tersebut bergenotipe hemizigot dan ada pula yang rasionya sebesar 0,25 yang berarti bahwa tanaman tersebut bergenotipe homozigot (Tabel 3).

\section{KESIMPULAN}

Teknologi ddPCR menawarkan sejumlah keunggulan dibanding teknik qPCR di antaranya mampu melakukan kuantifikasi absolut maupun relatif pada DNA dengan konsentrasi sangat rendah, tidak memerlukan kurva standar, serta tidak sensitif terhadap kehadiran senyawa inhibitor. Pada kegiatan analisis molekuler tanaman, teknologi ini dapat dimanfaatkan untuk melakukan pengukuran konsentrasi DNA tanaman secara akurat, deteksi kehadiran patogen pada jaringan tanaman, serta mengestimasi jumlah salinan DNA pada kegiatan transformasi genetik. Teknologi ini memiliki potensi sebagai powerful tool untuk membantu memecahkan berbagai masalah dan tantangan dalam bidang biologi molekuler dan diagnostik pada masa mendatang.

\section{UCAPAN TERIMA KASIH}

Penulis menyampaikan terima kasih kepada Dr. Sintho W. Ardie yang telah memberikan kesempatan untuk mempublikasikan tulisan ini.

\section{DAFTAR PUSTAKA}

Budiarto BR (2015) Polymerase Chain Reaction (PCR): perkembangan dan perannya dalam diagnostik kesehatan. BioTrends 6(2): 29-38.

Corman VM, Landt O, Kaiser M, Molenkamp R, Meijer A, Chu DKW, Bleicker T, Brünink S, Schneider J, Schmidt ML, Mulders DGJC, Haagmans BL, van der Veer B, van den Brink S, Wijsman L, Goderski G, Romette JL, Ellis J, Zambon M, Peiris M, Goossens H, Reusken C, Koopmans MPG, Drosten C (2020) Detection of 2019 novel coronavirus (2019-nCoV) by real-time RT-PCR. Euro Surveill. 25(3): 2000045.

Demeke T, Dobnik D (2018) Critical assessment of digital PCR for the detection and quantification of genetically modified organisms. Analytical and Bioanalytical Chemistry 410(17): 4039-4050. 
Dingle TC, Sedlak RH, Cook L, Jerome KR (2013) Tolerance of droplet-digital PCR vs real-time quantitative PCR to inhibitory substances. Clinical chemistry 59(11): 1670-1672.

Efendi R, Musa Y, Bdr MF, Rahim MD, Azrai M, Pabendon M (2015) Seleksi jagung inbrida dengan marka molekuler dan toleransinya terhadap kekeringan dan nitrogen rendah. Penelitian Pertanian Tanaman Pangan 34(1): 43-53.

Giraldo PA, Cogan NOI, Spangenberg GC, Smith KF, Shinozuka H (2019) Development and application of droplet digital PCR tools for the detection of transgenes in pastures and pasture-based products. Front. Plant Sci. 9:1923.

Gossen BD, Al-Daoud F, Dumonceaux T, Dalton JA, Peng G, Pageau D, McDonald MR 2019 Comparison of techniques for estimation of resting spores of Plasmodiophora brassicae in soil. Plant Pathology 68(5): 954-961.

Handoyo D, Rudiretna A (2000) Prinsip umum dan pelaksanaan Polymerase Chain Reaction (PCR). Unitas 9(1): 1729.

Hidayatun N, Chaerani, Utami DW (2011) Sidik jari DNA 88 plasma nutfah ubi jalar di Indonesia berdasarkan delapan penanda SSR. Jurnal AgroBiogen 7(2), 119-127.

Hindson BJ, Ness KD, Masquelier DA, Belgrade P, Heredia NJ, Makarewicz AJ, Bright IJ, Lucero MY, Hiddessen AL, Legler TC, Kitano TK, Hodel MR, Petersen JF, Wyatt PW, Steenblock ER, Shah PH, Bousse LJ, Troup CB, Mellen JC, Wittman DK, Erndt NG, Cauley TH, Koehler RT, So AP, Dube S, Rose KA, Montesclaros L, Wang S, Stumbo DP, Hodges SP, Romine S, Milanovich FP, White HE, Regan JF, Karlin-Neumann GA, Hindson CM, Saxonov S, Colston BW (2011) High-throughput droplet digital PCR system for absolute quantitation of DNA copy number. Analytical chemistry 83(22): 8604-8610.
Hou Y, Zhang H, Miranda L, Lin S (2010) Serious overestimation in quantitative pcr by circular (supercoiled) plasmid standard: Microalgal pena as the model gene. PLoS ONE 5(3): 1-7.Huggett JF, Novak T, Garson JA, Green C, MorrisJones SD, Miller RF, Zumla A (2008) Differential susceptibility of PCR reactions to inhibitors: An important and unrecognised phenomenon. BMC Research Notes 1: 1-9.

Iwobi A., Gerdes L, Busch U, Pecoraro S (2016) Droplet digital PCR for routine analysis of genetically modified foods (GMO) - a comparison with real-time quantitative PCR. Food Control 69: 205213.

Kim TG, Yi T, Cho KS (2013) Use of artificial DNA with multiple probe sites as reference DNA templates for quantitative real-time PCR to examine methanogen communities. Journal of Environmental Science and Health - Part A 48(4): 417-421.

Koepfli C, Nguitragool W, Hofmann NE, Robinson LJ, Ome-Kaius M, Sattabongkot J, Felger I, Mueller I (2016) Sensitive and accurate quantification of human malaria parasites using droplet digital PCR (ddPCR). Sci. Rep 6: 39183.

Kosir AB, Arulandhu AJ, Voorhuijzen MM, Xiao H, Hagelaar R, Staats M, Costessi A, Žel K, Kok EJ, van Dijk JP (2017) ALF: A strategy for identification of unauthorized GMOs in complex mixtures by a GW-NGS method and dedicated bioinformatics analysis. Sci Rep 7:14155.

Kusuma SB, Wairocana IGN (2013) Proses pembuktian seorang anak luar kawin terhadap ayah biologisnya melalui tes DNA. Kertha Semaya 1(10): 4-5.

Manoj P (2014) Droplet digital PCR technology promises new applications and research areas. Mitochondrial DNA: $1-5$.

Mao X, Liu C, Tong H, Chen Y, Liu K (2019) Principle of digital PCR and its application in current obstetrical and 
gynecological diseases. American Journal of Translational Research 11(12): 7209-7222.

Meitayani NPS, Adiartayasa W, Wijaya IN (2014) Deteksi penyakit Citrus Vein Phloem Degeneration (CVPD) dengan teknik Polymerase Chain Reaction (PCR) pada tanaman jeruk di Bali. J Agroeko Trop 3(2): 70-79.

Mullis K, Faloona F, Scharf S, Saiki RK, Horn GT, Erlich H (1986) Specific enzymatic amplification of DNA in vitro: the Polymerase Chain Reaction. In Cold Spring Harbor symposia on quantitative biology (Vol. 51, pp. 263273). Cold Spring Harbor Laboratory Press.

Noor SM (2018) Teknik molekuler amplifikasi DNA untuk deteksi Brucellosis pada sapi. Wartazoa 28(2): 81-88.

Nyaruaba R, Mwaliko C, Kering KK, Wei H (2019) Droplet digital PCR applications in tuberculosis world. Tuberculosis 117: 85-92.

Pardal SJ, Rahayu VR, Nugroho K, Suharsono (2020) Analisis keragaman genetik galur kedelai transgenik toleran cekaman aluminium dan varietas nontransgenik berdasarkan marka Simple Sequence Repeat (SSR). Penelitian Pertanian Tanaman Pangan 4(3): 171177.

Ristaino JB, Saville AC, Paul R, Cooper DC, Wei Q (2020) Detection of Phytophthora infestans by LoopMediated Isothermal Amplification, Real-Time LAMP, and droplet digital PCR. Plant Disease 104(3): 708-716.

Scollo F, Egea LA, Gentile A, La Malfa S, Dorado G, Hernandez P (2016) Absolute quantification of olive oil DNA by droplet digital-PCR (ddPCR): comparison of isolation and amplification methodologies. Food Chemistry 213: 388-394.

Sean T, Laperriere G, Germain H (2017) Droplet digital PCR versus $\mathrm{qPCR}$ for gene expression analysis with low abundant targets: from variable nonsense to publication quality data. Sci. Rep. 7: 2409.

Shiddieqy MI, Pratiwi N, Soewandi BDP (2014) Penggunaan marka molekuler untuk meningkatkan kualitas karkas sapi potong di Indonesia. Wartazoa 29(4): 193-204.

Suryadi T (2015) Teknik analisis DNA dalam mengidentifikasi genotip golongan darah pada jenazah kasus forensik. Jurnal Kedokteran Syiah Kuala 15(3): 157-161.

Sykes PJ, Neoh SH, Brisco MJ, Hughes E, Condon J, Morley AA (1992). Quantitation of targets for PCR by use of limiting dilution. Biotechniques 13(3): 444-449.

Terryana RT, Nugroho K, Rijzaani H, Lestari P (2018) Karakterisasi keragaman genetik 27 genotipe cabai berdasarkan marka SSR (Simple Sequence Repeat). Berita Biologi 17(2): 183-194. Whale AS, Huggett JF, Cowen S, Speirs V, Shaw J, Ellison S, Foy CA, Scott DJ (2012) Comparison of microfluidic digital PCR and conventional quantitative PCR for measuring copy number variation. Nucleic Acids Research 40(11): 1-9.

Wu Y, Li J, Li X, Liang J, Li Y, Zeng X, Wu G (2017). Copy number and zygosity determination of transgenic rapeseed by droplet digital PCR. Oil Crop Science 2(2): 84-94.

Yang R, Paparini A, Monis P, Ryan U (2014) Comparison of next-generation droplet digital PCR (ddPCR) with quantitative PCR (qPCR) for enumeration of Cryptosporidium oocysts in faecal sample. International Journal of Parasitology 44(14): 1105-1113.

Zhao Y, Xia Q, Yin Y, Wang Z (2016) Comparison of droplet digital PCR and quantitative PCR assays for quantitative detection of Xanthomonas citri subsp. citri. PloS One 11(7): 1-18. 